\title{
Analysis of Structure and Efficiency of Cassava Marketing in Ado-Ekiti Local Government Area of Ekiti State, Nigeria
}

\author{
${ }^{*}$ H. Egwuma, A. E. Muhammed, O. A. Ojeleye, Y. U. Oladimeji and A. A. Hassan \\ Department of Agricultural Economics, Faculty of Agriculture, Ahmadu Bello University, Zaria. \\ [Corresponding Author: E-mail: henry4him@gmail.com;_E: +2348057161188]
}

\section{ABSTRACT}

The study examined the structure and marketing efficiency of cassava in Ado-Ekiti Local Government Area of Ekiti State, Nigeria. Primary data were obtained using structured questionnaires and multistage sampling method was employed to select 183 respondents comprising 93 farmers and 90 marketers. The HerfindahlHirschman Index and Gini Coefficient were used to measure the degree of market concentration and the nature of competition in the market. The Herfindahl-Hirschman indices were $0.323,0.346$, and 0.316 for farmers, wholesalers, and retailers, respectively, suggesting that the market was uncompetitive at all levels. The computed values of Gini coefficient for cassava farmers, wholesalers, and retailers were $0.532,0.465$, and 0.569 , respectively, indicating uneven distribution of income and uncompetitive market conditions. Two channels of cassava marketing were identified and the study demonstrates that the farmer-wholesalerretailer-consumer channel had higher marketing efficiency and thus provides marketers with better opportunities for making more profits. Based on the findings, it is recommended that micro credit facilities should be made accessible to market actors to encourage investment and improve efficiency in cassava marketing.

Keywords: Cassava, marketing efficiency, Ekiti, Herfindahl-Hirschman Index, Gini Coefficient

\section{INTRODUCTION}

Root and tuber crops are among the most important groups of staple foods in many tropical African countries and constitute the largest source of calories for the Nigeria population (Olaniyan et al., 2001; Abdulrahman et al., 2016). Cassava (Manihot esculenta) is the most important of these crops in terms of total production, followed by yam (Dioscorea spp), Cocoyam (Colocasia spp and Xanthosoma spp) and sweet potato (Ipomoea batatas) (Olaniyan et al., 2001).

Cassava is an important staple food in Africa, especially in Nigeria where it plays a major role in the food economy and has traditionally been a subsistence crop of predominantly low-income families in rural and urban areas of Nigeria (Adebayo et al., 2009). Since cassava thrives well in low rainfall areas with poor soils and requires very little investment during the production cycle, the crop is well embraced by resource-poor small-scale farmers. A large population of Nigeria depends on cassava daily as their main dishes such as gari and fufu. The leaves are consumed as vegetable, and it serves as raw material for industries as well as a means of alleviating poverty.

Cassava has assumed particular importance because approximately two-thirds of the world's cassava production takes place in West Africa and mainly in Nigeria. According to the Food and Agriculture Organization of the United Nations (2018), Nigeria is the world's largest producer of cassava with a production of about 59 million tons in 2017 over a cultivated area of about 3.7 million ha. Cassava is produced largely by small scale farmers using rudimentary implements and capital is a major limiting factor as only few farmers have access to rural credit. The average land-holding is less than two hectares and for most farmers; land and family labour remain the essential input. 
In Nigeria, as in many developing countries, smallholder farmers are faced with numerous complex challenges including low crop yields, poor infrastructure, poor access to credit and extension services, inefficient and unorganized marketing systems, and information asymmetries which act to increase transaction costs of accessing the input and output markets (Bernard, et al., 2010; Mojo et al., 2017; Abdul-Rahaman and Abdulai, 2018). These problems hinder the growth of competitive markets and limit the opportunity of farmers to raise their incomes and improve their livelihoods. Consequently, addressing these myriads of constraints in order to encourage the emergence of well-structured and efficiently organized marketing systems is particularly important.

To increase the competitiveness of cassava in the domestic and international markets, there is a need for public-private efforts to be intensified in ensuring efficiency in the marketing system. An efficient marketing system increases producers' share in consumer price, improves rural incomes and revenue generation for both producers and marketers, and significantly contributes to sustainable agricultural development (Enibe et al., 2008; Kumar, 2014; Ruttoh et al., 2018). Through various policies and initiatives, the government of Nigeria has expressed its determination in developing the cassava value chain and creating efficient markets for farmers. However, smallholder cassava farmers have continued to face problems in the marketing of their produce due to widespread inefficiencies within the marketing system, resulting in significant differential between consumer and producer prices.

This study provides some evidence that may help in understanding the structure under which cassava marketing is promoted. By analyzing the structure and efficiency of cassava marketing, we hope that the findings of this study will help in the design of effective policies and strategies towards improving efficient marketing systems.

\section{MATERIALS AND METHODS Description of Study Area}

This study was conducted in Ado-Ekiti Local Government Area (LGA) of Ekiti State, Nigeria. Ado-Ekiti LGA is located between latitude $7^{\circ} 37^{\prime} 16^{\prime \prime} \mathrm{N}$ and $5^{\circ} 13^{\prime} 17^{\prime \prime} \mathrm{E}$ and between longitude $7.62111^{\circ} \mathrm{N} 5.22139^{\circ} \quad \mathrm{E}$. It shares boundaries with Ikere and Iseorun in the south, Gboyin in the east, Ido-Osi and Oye in the north, and Ekiti West and ljero in the west. Ado-Ekiti has a total land area of $293 \mathrm{~km}^{2}$ and elevation of $455 \mathrm{~m}$ above the sea level with a projected population of 427,700 in 2016 (National Population Commission of Nigeria, 2006). It is a town in the southern guinea savannah of the ecological zones of Nigeria. The local government has a distinct wet and dry season. The rainy season lasts from April to October while the dry season falls between November and March. The majority of the people of this LGA are small-scale farmers and the rich and diversified soil condition enable agriculture to thrive in this area. The climate of this area is tropical and the good soil condition favours the growth of crops such as yam, cassava, maize, potato, vegetable, pulses, and tree crops such as plantain, cocoa, banana, cashew, mango, kola nut, and guava. The local government has 13 wards with Idofin as the administrative headquarters.

\section{Sampling Procedure and Sample Size}

A two-stage sampling method was used to select the respondents in the study area. The first stage involved purposive selection of 5 wards out of 13 in the study area. The selected wards are those with registered cassava farmers. The second stage consisted of random selection of 93 cassava-producing farmers from the total population size of 122 registered cassava farmers using the formula proposed by Yamane (1967) and adopted by Oladimeji et al. (2017) and Egwuma et al. (2019).

$$
n_{0}=\frac{N}{1+N\left(e^{2}\right)}
$$




\section{Nigerian Journal of Basic and Applied Science (December, 2019), 27(2): 62-69}

Where: $\quad n_{0}$ is the sample size without considering the finite population correction factor; $e=0.05 ; N=$ total number of observation.

In addition, purposive sampling method was used to select 10 marketers each from 9 wards making a total of 90 cassava marketers. The reason for this sampling method is that cassava markets are available in only nine wards out of the thirteen wards in the study area. Furthermore, the wards are homogeneous and cassava marketing is a common activity in the study area.

\section{Analytical Techniques}

This study employed the Herfindahl-Hirschman Index $(\mathrm{HHI})$ and the Gini Coefficient $(\mathrm{GC})$ to measure the degree of market concentration and the nature of competition in the market for cassava. Market concentration measures the share of total transaction or sales by a given number of market participants in a particular market. The HHI can be expressed as follows:

$$
H H I=\sum_{i=1}^{t} M S^{2}
$$

Where $M S$ represents the market share for seller $i$ and $t$ is the total number of sellers in the market. The market share, $M S$, which refers to the proportion of the sales of a seller relative to others is given as follows:

$M S_{i}=\frac{Q_{i}}{\sum_{i}^{t} Q_{i}}$

Where $Q_{i}$ is the quantity of cassava handled by seller $i$ and $\sum Q_{i}$ is the sum of cassava handled by all the sellers in the market. Following Krivka (2016), Hrazdil and Zhang (2012), and Ruttoh et al. (2018), if the $\mathrm{HHI}$ is less than 0.1 the market is said to be unconcentrated, indicating a competitive market condition. $\mathrm{HHI}$ of between 0.1 and 0.18 represents moderate concentration and $\mathrm{HHI}$ of more than 0.18 indicates high market concentration.

The Gini Coefficient model can be expressed as follows:

$$
G C=1-\sum X Y
$$

Where $G C=$ Gini Coefficient, $X=$ percentage share of each seller per period of study, $Y=$ cumulative percentages of total sales (revenue). The GC has a value ranging from 0 to 1 , indicating the extent to which the market is concentrated. Gini coefficient is equal to 0 when the market is perfect and competitive and 1 when the market is imperfect.

Marketing efficiency was used to determine how efficient the markets are in terms of cassava marketing. Marketing efficiency can be expressed as follows:

Marketing Efficiency

$=\frac{\text { Value added by marketing per ton }}{\text { cost of marketing activities per ton }} * 100$

Where,

Value added by marketing $=$ Retail price less the producer price

Cost of marketing activities $=$ Cost of transport, commission agent share, loading and off loading.

The results of the $H H I, G C$ and marketing efficiency are all presented using Tables.

\section{RESULTS AND DISCUSSION Market Concentration of Cassava Producers}

The $\mathrm{HHI}$ of cassava producers is reported in Table 1. The value of the $\mathrm{HHI}$ of cassava producers is 0.323 indicating that the market structure at the producer level exhibits an oligopolistic nature. This implies that a large proportion of cassava produced and sold is controlled by a few producers. In addition, the GC at the producer level is 0.532 and signifies an imperfect market with a high level of inequality in the distribution of sales revenue (Table 2). Furthermore, the results show that about $27.9 \%$ of cassava producers each earned $\$ 30,000$ and below, representing $10.7 \%(\$ 524,000)$ of the total sales revenue of $\$ 4,877,600$ while $36.6 \%$ of producers made $\$ 31,000-60,000$ each which account for $30.1 \%(\$ 1,467,600)$ of total sales income. Also, $30.1 \%$ of producers made about \#61,000-120,000 representing $44.8 \%$ 
$(\mathrm{A} 2,188,000)$ of total sales income while $5.4 \%$ of producers earned above $\mathrm{N120,000}$ each which account for $14.4 \%(\$ 698,000)$ of total sales revenue. This high variation in sales revenue reveals uncompetitive market conditions where some cassava producers have high market power and could influence the price and other marketers in the area. The result corroborates the findings of Afolabi (2009) and Ruttoh et al. (2018).

Table 1:Herfindahl-Hirschman Index for cassava producers in Ado-Ekiti

\begin{tabular}{lccc}
\hline $\begin{array}{l}\text { Range of Quantity } \\
\text { of Cassava } \\
\text { Produced }(\mathbf{K g})\end{array}$ & $\begin{array}{c}\text { Quantity of } \\
\text { Cassava Produced } \\
(\mathbf{K g})\end{array}$ & $\begin{array}{c}\text { Market Share } \\
\left(\boldsymbol{M} \boldsymbol{S}_{\boldsymbol{i}}\right)\end{array}$ & $\begin{array}{c}\text { Square of Market } \\
\text { share }\left(\boldsymbol{M S}^{\mathbf{2}}\right)\end{array}$ \\
\hline$\leq 2,000$ & 48,400 & 0.1684650 & 0.0283804 \\
$2,001-4,000$ & 134,200 & 0.4671076 & 0.2181895 \\
$4,001-6,000$ & 76,200 & 0.2652280 & 0.0703459 \\
$6,001-8,000$ & 20,000 & 0.0696136 & 0.0048460 \\
$>8,000$ & 8,500 & 0.0295858 & 0.0008753 \\
Total & 287,300 & 1 & $\mathbf{0 . 3 2 2 6 3 7 1}$ \\
\hline
\end{tabular}

Source: Field Survey, 2018

Table 2: Gini coefficient for cassava producers in Ado-Ekiti

\begin{tabular}{|c|c|c|c|c|c|c|c|c|}
\hline $\begin{array}{l}\text { Income Range } \\
\text { (A) }\end{array}$ & Freq & $\begin{array}{l}\text { Cum } \\
\text { ul. } \\
\text { Freq. }\end{array}$ & $\begin{array}{l}\text { Proporti } \\
\text { on of } \\
\text { Produce } \\
\text { rs (X) }\end{array}$ & $\begin{array}{l}\text { Cumul. } \\
\text { Proport } \\
\text { ion of } \\
\text { produc } \\
\text { ers } \\
\end{array}$ & $\begin{array}{c}\text { Total } \\
\text { Sales } \\
\text { Revenue } \\
\text { (N) }\end{array}$ & $\begin{array}{c}\text { Propor } \\
\text { tion of } \\
\text { Sales }\end{array}$ & $\begin{array}{l}\text { Cumul. } \\
\text { Proporti } \\
\text { on of } \\
\text { Sales (Y) }\end{array}$ & $\overline{X Y}$ \\
\hline$\leq 30,000$ & 26 & 26 & 0.279 & 0.279 & 524,000 & 0.107 & 0.107 & 0.030 \\
\hline $31,000-60,000$ & 34 & 60 & 0.366 & 0.645 & $1,467,600$ & 0.301 & 0.408 & 0.149 \\
\hline $61,000-90,000$ & 24 & 84 & 0.258 & 0.903 & $1,781,800$ & 0.365 & 0.773 & 0.199 \\
\hline $91,000-120,000$ & 4 & 88 & 0.043 & 0.946 & 406,200 & 0.083 & 0.856 & 0.037 \\
\hline $121,000-150,000$ & 4 & 92 & 0.043 & 0.989 & 544,000 & 0.112 & 0.968 & 0.042 \\
\hline$>150,000$ & 1 & 93 & 0.011 & 1 & 154,000 & 0.032 & 1 & 0.011 \\
\hline Total & 93 & & 1 & & $4,877,600$ & 1 & & 0.468 \\
\hline \multicolumn{9}{|c|}{ Gini Coefficient $=1-\sum X Y=1-0.468=\mathbf{0 . 5 3 2}$} \\
\hline
\end{tabular}

\section{Market Concentration of Cassava Wholesalers}

The results of the $\mathrm{HHI}$ and GC for cassava wholesalers are presented in Tables 3 and 4 , respectively. The estimated value of the $\mathrm{HHI}$ for wholesalers is 0.346 which means that cassava market at the wholesale level is highly concentrated, reflecting uncompetitive condition. The computed GC is 0.465 and implies a high variation in sales revenue at the wholesale level. In particular, about $45.2 \%$ of wholesalers each earned $\$ 50,000$ and below which account for
$23.6 \%(\mathrm{~A} 623,500)$ of total sales revenue of A2,642,200 while $42.9 \%$ of wholesalers made A $51,000-100,000$ each which account for $50.5 \%$ $(\mathrm{A} 1,335,200)$ of total sales income. Also, $11.9 \%$ of wholesalers earned above $\mathrm{A} 100,000$ each reflecting 25.9\% ( $(\mathrm{A} 683,500)$ of total sales revenue. This result suggests a very high variation in revenue obtained from the sale of cassava amongst the wholesalers, reflecting inefficient and uncompetitive market conditions. The result is consistent with the findings of 
Issahaku et al. (2012), Eronmwon et al. (2014), Nzima and Dzanja (2015), and Fadipe et al.
(2015) that reported high inequality in incomes at the wholesale level of marketing.

Table 3: Herfindahl-Hirschman Index for cassava wholesalers in Ado-Ekiti

\begin{tabular}{lccc}
\hline $\begin{array}{l}\text { Range of Quantity } \\
\text { of Cassava } \\
\text { handled }(\mathrm{Kg})\end{array}$ & $\begin{array}{c}\text { Quantity of } \\
\text { Cassava sold per } \\
\text { time period }(\mathrm{Kg})\end{array}$ & $\begin{array}{c}\text { Market Share } \\
\left(\boldsymbol{M} \boldsymbol{S}_{\boldsymbol{i}}\right)\end{array}$ & $\begin{array}{c}\text { Square of Market } \\
\text { share }\left(\boldsymbol{M S}^{\mathbf{2}}\right)\end{array}$ \\
\hline$\leq 500$ & 3,300 & 0.0784780 & 0.0061588 \\
$501-1,000$ & 22,050 & 0.5243757 & 0.2749699 \\
$1,001-1,500$ & 8,700 & 0.2068966 & 0.0428062 \\
$1,501-2,000$ & 5,900 & 0.1403092 & 0.0196867 \\
$>2,000$ & 2,100 & 0.0499405 & 0.0024941 \\
Total & 42,050 & 1 & $\mathbf{0 . 3 4 6 1 1 5 7}$ \\
\hline
\end{tabular}

Source: Field Survey, 2018

Table 4: Gini Coefficient for Cassava Wholesalers in Ado-Ekiti

\begin{tabular}{lcccccccc}
\hline $\begin{array}{c}\text { Income Range } \\
(\mathbf{N})\end{array}$ & Freq & $\begin{array}{c}\text { Cumu } \\
\text { I. } \\
\text { Freq. }\end{array}$ & $\begin{array}{c}\text { Proport } \\
\text { ion of } \\
\text { Produc } \\
\text { ers (X) }\end{array}$ & $\begin{array}{c}\text { Cumul. } \\
\text { Proport } \\
\text { ion of } \\
\text { produc } \\
\text { ers }\end{array}$ & $\begin{array}{c}\text { Total } \\
\text { Sales (A) }\end{array}$ & $\begin{array}{c}\text { Proport } \\
\text { ion of } \\
\text { Sales }\end{array}$ & $\begin{array}{c}\text { Cumul. } \\
\text { Proporti } \\
\text { on of } \\
\text { Sales (Y) }\end{array}$ & XY \\
\hline$\leq 50,000$ & 19 & 19 & 0.452 & 0.452 & 623,500 & 0.236 & 0.236 & 0.107 \\
$51,000-100,000$ & 18 & 37 & 0.429 & 0.881 & $1,335,200$ & 0.505 & 0.741 & 0.318 \\
$101,000-150,000$ & 4 & 41 & 0.095 & 0.976 & 443,500 & 0.168 & 0.909 & 0.086 \\
$>150,000$ & 1 & 42 & 0.024 & 1 & 240,000 & 0.091 & 1 & 0.024 \\
Total & 42 & & 1 & & $2,642,200$ & 1 & & 0.535 \\
Gini Coefficient $=1-\sum X Y=1-0.535=0.465$ & & & & & \\
\hline
\end{tabular}

Source: Field Survey, 2018

\section{Market Concentration of Cassava Retailers}

Tables 5 and 6 show the results of the $\mathrm{HHI}$ and $\mathrm{GC}$ for cassava retailers. The $\mathrm{HHI}$ value of 0.316 reflects a highly concentrated market at the retail level, indicating uncompetitive market condition. The computed GC is 0.569 , which further supports this conclusion and implies an economically inequitable distribution of trade volume among cassava retailers in the study area. About $25 \%$ of retailers each earned A20,000 and below which account for $8.7 \%$ $(\mathrm{A} 188,100)$ of total sales revenue of $\mathrm{A2}, 153,300$ while $35.4 \%$ of retailers made $\$ 21,000-40,000$ each which account for $25.6 \%$ ( $\$ 550,800)$ of total sales income. Furthermore, $35.4 \%$ of retailers earned $\$ 41,000-100,000$ each reflecting $52.2 \%$ $(A 1,124,400)$ of total sales income while about
$4.2 \%$ made above 100,000 each reflecting $13.5 \%$ (A290,000) of total sales income.

Overall, we find a high level of inequality in the distribution of income at the three levels of cassava marketing in the study area. This could be attributed to low access to adequate capital by most of the various agents, which limits their ability to invest in cassava marketing. According to Ruttoh et al. (2018), capital is a very critical factor in marketing and determines the level of investments, and hence, earnings. In addition, agricultural marketing inherently involves risk and market actors who engage in risky investments are likely to make more profits (Giroh et al., 2010). Our results are similar to the findings of Fadipe et al. (2015), Nzima and Dzanja (2015), 
Abah et al. (2015), and Ruttoh et al. (2018) who found evidence of the existence of high variation of income distribution in marketing of agricultural commodities. These studies suggested that high- income inequalities among market actors could be credited to wide variations in investment levels and probably barriers to entry.

Table 5: Herfindahl-Hirschman Index for cassava retailers in Ado-Ekiti

\begin{tabular}{lccc}
\hline $\begin{array}{l}\text { Range of Quantity } \\
\text { of Cassava } \\
\text { handled (Kg) }\end{array}$ & $\begin{array}{c}\text { Quantity of } \\
\text { Cassava sold per } \\
\text { time period }(\mathrm{Kg})\end{array}$ & $\begin{array}{c}\text { Market Share } \\
\left(\boldsymbol{M S}_{\boldsymbol{i}}\right)\end{array}$ & $\begin{array}{c}\text { Square of Market } \\
\text { share }\left(\boldsymbol{M S}^{\mathbf{2}}\right)\end{array}$ \\
\hline$\leq 200$ & 100 & 0.0027473 & 0.0000075 \\
$201-400$ & 300 & 0.0082417 & 0.0000679 \\
$401-600$ & 9,500 & 0.2609890 & 0.0681153 \\
$601-800$ & 5,900 & 0.1620879 & 0.0262724 \\
$801-1,000$ & 16,700 & 0.4587912 & 0.2104894 \\
$>1,000$ & 3,900 & 0.1071429 & 0.0114796 \\
Total & 36,400 & 1 & $\mathbf{0 . 3 1 6 4 3 2 1}$ \\
\hline
\end{tabular}

Source: Field Survey, 2018

Table 6: Gini Coefficient for Cassava Retailers in Ado-Ekiti

\begin{tabular}{|c|c|c|c|c|c|c|c|c|}
\hline $\begin{array}{l}\text { Income Range } \\
\text { (A) }\end{array}$ & Freq. & $\begin{array}{c}\text { Cumu } \\
\text { I. } \\
\text { Freq. }\end{array}$ & $\begin{array}{c}\text { Proporti } \\
\text { on of } \\
\text { Produce } \\
\text { rs (X) }\end{array}$ & $\begin{array}{l}\text { Cumul. } \\
\text { Proporti } \\
\text { on of } \\
\text { produce } \\
\text { rs }\end{array}$ & $\begin{array}{c}\text { Total } \\
\text { Sales (N) }\end{array}$ & $\begin{array}{l}\text { Proportio } \\
n \text { of Sales }\end{array}$ & $\begin{array}{c}\text { Cumul. } \\
\text { Proporti } \\
\text { on of } \\
\text { Sales }(Y)\end{array}$ & $\overline{\mathrm{XY}}$ \\
\hline$\leq 20,000$ & 12 & 12 & 0.250 & 0.250 & 188,100 & 0.087 & 0.087 & 0.022 \\
\hline $21,000-40,000$ & 17 & 29 & 0.354 & 0.604 & 550,800 & 0.256 & 0.343 & 0.121 \\
\hline $41,000-60,000$ & 7 & 36 & 0.146 & 0.750 & 368,500 & 0.171 & 0.514 & 0.075 \\
\hline $61,000-80,000$ & 9 & 45 & 0.187 & 0.937 & 655,900 & 0.305 & 0.819 & 0.153 \\
\hline $81,000-100,000$ & 1 & 46 & 0.021 & 0.958 & 100,000 & 0.046 & 0.865 & 0.018 \\
\hline$>100,000$ & 2 & 48 & 0.042 & 1 & 290,000 & 0.135 & 1 & 0.042 \\
\hline Total & 48 & & 1 & & $\begin{array}{c}2,153,30 \\
0\end{array}$ & 1 & & 0.431 \\
\hline \multicolumn{9}{|c|}{ Gini Coefficient $=1-\sum X Y=1-0.431=0.569$} \\
\hline
\end{tabular}

\section{Marketing Efficiency}

There are two major channels of cassava marketing in the study area. Marketing Channel 1 involved farmers who sold cassava directly to retailers who, in turn, sold to the final consumers. In Channel 2, farmers sold cassava to wholesalers. The wholesalers, in turn, sold to the retailers, and the retailers then sold to the final consumers. The results of marketing efficiency based on these two channels are reported in Table 7. In Channel 1, the average cost of marketing was $A 3,270$ but the value added through marketing was $\$ 6,730$ while in Channel 2 the average cost of marketing was $\mathrm{A} 3,950$ but the value added through marketing was $\mathrm{A} 10,120$. The results reveal that the marketing efficiency for Channels 1 and 2 are $205.81 \%$ and $256.20 \%$, respectively. This implies that cassava marketing through channel 2 was more efficient than channel 1 and marketers can find better opportunities for making more profits through channel 2. 
Table 7: Marketing efficiency of cassava marketers in Ado-Ekiti

\begin{tabular}{lcc}
\hline Parameters & Channel 1 & Channel 2 \\
\hline Producer price of cassava (A/ton) A & 26,410 & 26,410 \\
Selling Price (A/ton) B & 33,140 & 36,530 \\
Value added (A/ton) B-A & 6,730 & 10,120 \\
Marketing cost (A) & & \\
Transport (A) & 2,500 & 3,000 \\
Loading/off-loading (A) & 600 & 750 \\
Commission agents (A) & 170 & 200 \\
Total marketing cost (A) C & 3,270 & 3,950 \\
Marketing Efficiency $\frac{B-A}{C} * 100(\%)$ & 205.81 & 256.20 \\
\hline
\end{tabular}

Source: Field Survey, 2018

\section{CONCLUSION}

The analysis of cassava marketing in the study area shows that cassava marketing was characterized by imperfect competition where a few actors controlled larger shares of marketed output at all levels. The computed values of Gini coefficient for cassava farmers, wholesalers, and retailers reveal that income is not equally distributed, indicating imperfect markets. A larger share of cassava sales revenue is in the hands of few marketers. The study further shows that cassava marketing in the study area consisted of two channels producing different levels of value addition. The results show that channel 2 comprising of farmer-wholesaler-retailerconsumer had higher marketing efficiency and marketers can find better opportunities for making more profits through channel 2. Based on the findings of this study, it is recommended that micro credit facilities should be made accessible to market actors to encourage investment in cassava marketing.

\section{REFERENCES}

Abah, A. D., Abu, G. and Ater, P. (2015).Analysis of the structure and conduct of paddy rice marketing in Benue state, Nigeria. American Journal of Marketing Research, 1(2): 70-78.

Abdul-Rahaman, A. and Abdulai, A. (2018). Do farmer groups impact on farm yield and efficiency of smallholder farmers?
Evidence from rice farmers in northern Ghana. Food Policy, 81: 95-105.

Abdulrahman, S., David, A. I,, Yusuf, O., Abdulazeez, R.O. and Binuyo, G. (2016). Analysis of livelihood diversification by farming households in Kaduna State, Nigeria.2nd International conference on Dry land Agriculture, Centre for Dryland Agriculture, Bayero University, Kano. 12th -16th December, 2016. Pp 45-49.

Adebayo, K., Lamboll, R. and Westby, A. (2009). Social implications of the development of cassava postharvest systems in Africa. Expert Consultation at the Natural Resource Institute. Retrieved from Available:(http://www. nri. org/projects/GCPMD/files/2 Adebayo paper. pdf). University of Greenwich, United Kingdom.

Afolabi, J. A. (2009). An assessment of garri marketing in South-Western Nigeria. Journal of Social Sciences, 21(1): 33-38.

Bernard, T., Spielman, D. J., Taffesse, A. S. and Gabre-Madhin, E. Z. (2010). Cooperatives for staple crop marketing: evidence from Ethiopia. Washington, DC: International Food Policy Research Institute (IFPRI) Research Report 166.

Egwuma, H., Oladimeji, Y. U., Muhammed, A. E., Ojeleye, O. A. and Abdulrahman, S. (2019). Profitability estimate of small- 
scale cassava production in Ado-Ekiti Local Government Area of Ekiti State, Nigeria. Dutse Journal of Agriculture and Food Security (DUJAFS), 6(1): 120-127.

Enibe, D. O., Chidebelu, S. A. N. D., Onwubuya, E. A., Agbo, C. and Mbah, A. A. (2008). Policy issues in the structure, conduct and performance of Banana Market in Anambra State, Nigeria. Journal of Agricultural Extension, 12(2): 32-40.

Eronmwon, I., Alufohai, G. O. and AdaOkungbowa, C. I. (2014). Structure, conduct and performance of plantain marketing in Edo State, Nigeria. Journal of Applied Sciences and Environmental Management, 18(3): 437-440.

Fadipe, A. E. A., Adenuga, A. H., and Raji, U. A. (2015).Analysis of cocoyam marketing in Sagamu Local Government Area, Ogun State, Nigeria. Trakia Journal of Sciences, 13(3): 208-213.

FAOSTAT. (2018). Food and Agriculture Organization of the United Nations. Available online at: http://faostat.fao.org/.

Giroh, D. Y., Umar, H. Y. and Yakub, W. (2010). Structure, conduct and performance of farm gate marketing of natural rubber in Edo and Delta States, Nigeria. African Journal of Agricultural research , 5(14): 1780-1783.

Hrazdil, R. and Zhang, R. (2012).The Importance of industry classification in concentration ratios. Economic Letters, 114(2): 224227.

Issahaku, H., Paul, K. N. and Yazidu, U. (2012). Structure, conduct and performance of tomato marketing in Ghana. Journal of Economics and Sustainable Development, 3(10): 222-235.

Krivka, A. (2016). On the concept of market concentration, the minimum HerfindahlHirschman Index, and its practical application. PANOECONOMICUS. 63(5): 525-540.

Kumar, S. (2014). Marketing efficiency analysis: A case of broiler marketing in Anand district of Gujarat. Int. J. Comm. \& Bus. Manage, 7(1): 186-190.

Mojo, D., Fischer, C., and Degefa, T. (2017). The determinants and economic impacts of membership in coffee farmer cooperatives: recent evidence from rural Ethiopia. Journal of Rural Studies, 50: 84-94.

National Population Commission. (2006). Population Census of the Federal Republic of Nigeria.Census Report. National Population Commission, Abuja.

Nzima, W. M. and Dzanja, J. (2015). Efficiency of soybean markets in Malawi: structure, conduct and performance approach. International Journal of Business and Social Science, 6(4): 162170.

Oladimeji, Y. U., Ajao, A. M.,Abdullahi, A. N., Abdulsalam, Z. and Damisa, M. A. (2017). Adoption of improved technologies and management practices among bee farmers in north central and north western Nigeria towards sustainable development goals. Ethiopian Journal Applied Sciences and Technology, 8(1): 1-13.

Olaniyan, G. O., Manyoung, V. M. and Oyewole, B. (2001).The dynamics of the root and tuber cropping systems in the middle belt of Nigeria. In: Akoroda, M. O. and Ngeve, J. M. (eds.). Proceedings of the $7^{\text {th }}$ Triennial Symposium of the International Society for Tropical Root Crops (ISTRC), Pp $75-81$.

Ruttoh, J.K., Bett, E. K. and Nyairo, N. (2018). Empirical analysis of structure and conduct of tomato marketing in Loitoktok, Kajiado County, kenya. International journal of Agricultural Extension and Rural Development, 6(4):628-638 